\title{
APPELLATE REVIEW OF SENTENCING PROCEDURE
}

Using a novel approach to avoid the longstanding rule that a federal appellate court will not review a criminal sentence, the Court of Appeals for the District of Columbia, in Leach v. United States, ${ }^{1}$ recently set aside the sentence of a convicted defendant. William Leach had been convicted of robbery in the District Court for the District of Columbia. When he appeared for sentencing he asked the judge to refer him for a mental examination. Although there was some evidence that Leach had previously been under psychiatric care, ${ }^{2}$ the trial judge denied his request and imposed sentence. The Court of Appeals affirmed the conviction. However the case was remanded to the district court for reconsideration of the sentence with a broad hint that Leach's request for psychiatric examination be honored. ${ }^{3}$ On remand the trial judge reimposed the same sentence without granting the requested examination." The judge gave four reasons for his action: the probation officer had recommended the maximum sentence and had not himself referred Leach for a mental examination as he had the power to do ; the crime was a serious one; the defendant had a record of repeated robberies; there was no competent evidence that the defendant at any time suffered from mental illness. ${ }^{6}$ The Court of Appeals rejected these reasons as support for the reimposition of the original sentence. Although the court recognized the general rule precluding appellate review of criminal sentences, it held that, "The adamant refusal in this case to refer the prisoner for a mental examination was an abuse of discretion."7 The court emphasized the fact that three alternative statutory procedures for determining mental competence were available to the trial judge, ${ }^{8}$ and based its decision on

1. 334 F.2d 945 (D.C. Cir. 1964). The original decision, dated April 9, was amended on May 11 and 19, 1964. Petitions for rehearing en banc and for rehearing by the Division were denied on June 11.

2. Leach himself stated that he had been twice under psychiatric carc. His lawyer told the court that during the last 31 years Leach had been out of jail only 63 days. Id. at 946 .

3. 320 F.2d 670,673 (D.C. Cir. 1963).

4. 218 F. Supp. 271 (D.D.C. 1963).

5. D.C. Code § 24-106 (1961) sets up the Legal Psychiatric Services. The statute provides in pertinent part that there shall be a "qualified psychiatrist and a qualified psychologist whose services shall be available ... in criminal cases to the judges and probation officers of the district court ... to assist them in carrying out their duties."

6. 334 F.2d 945, 947 (D.C. Cir. 1964).

7. Id. at 948.

8. a) D.C. Code $\$ 24-106$ (1961), discussed in note 5 supra, sets up the Legal Psychiatric Services.

b) D.C. Code $\$ 24-301$ (a) (1961) allows a court in its discretion to refer a convicted defendant to a mental hospital for examination prior to imposition of sentence.

c) Rule 35, Fro. R. CRrMr. P., provides that "the court may reduce a sentence within 60 days after the sentence is imposed." Thus the trial judge could have imposed a sentence, referred the petitioner for a mental examination, and deferred a possible reduction of the sentence until he learned of the outcome of the examination.

The dissent makes a telling point here, arguing that the legislative history of the above statutes does not support the interpretation given them by the majority. 334 F.2d at 951- 
the principle that "the sentencing judge should use some of the resources which Congress has provided and ... he may not arbitrarily ignore the data properly obtained thereby." the defendant's request for a mental examination before re-sentencing.

The striking fact of the Leach case lies in its review of the sentence imposed by the trial judge. It has long been a uniform policy of federal appellate courts not to consider a sentence within the statutory limits. The leading case cited for this rule of non-review is Gurera $v$. United States. ${ }^{10}$ In refusing to review a sentence the Eighth Circuit stated: "If there is one rule in the federal criminal practice which is firmly established, it is that the appellate court has no control over a sentence which is within the limits allowed by statute."11 Two years later in Blockburger v. United States, ${ }^{12}$ the Supreme Court upheld the imposition of consecutive sentences on multiple counts, deferring to the decision of the trial court as regards the sentence:

Under the circumstances so far disclosed, it is true that the imposition of the full penalty of fine and imprisonment upon each count seems unduly severe; but there may have been other facts and circumstances before the trial court properly influencing the extent of the punishment. In any event, the matter was one for that court, with whose judgment there is no warrant for interference on our part.13

With the exception of Blockburger, it has been the courts of appeals rather than the Supreme Court which have articulated the rule of non-review. A

58. Although the wording and history of the statutes indicate that Congress was merely making optional techniques available to the trial judge, the Court of Appeals is actually developing a new common law rule that where optional facilities are available, the sentencing judge must make use of at least one possible method.

9. 334 F.2d $945,951 \&$ n.16 (D.C. Cir. 1964).

10. 40 F.2d 338 (8th Cir. 1930).

11. Id. at 340. The "firm" establishment of this rule at the time of Gurcra may be open to some doubt in view of the history of appellate review. The federal appellate courts reviewed the merits of criminal sentences for a brief period of time in the last quarter of the 19th century. Section 3 of the Act of March 3, 1879 (20 Stat. 354, ch. 176) provided that: "In case of an affirmance of the judgment of the District Court, the Circuit Court shall proceed to pronounce final sentence and to award execution thereon." Two cases - Bates v. United States, 10 Fed. 92 (C.C.N.D. Ill. 1881), and United States v. Wyun, 11 Fed. 57 (C.C.E.D. Mo. 1882) - construed the statute as permitting circuit courts to modify sentences within statutory limits but considered too severe by appellate courts. However, when the appellate jurisdiction of the circuit courts was transferred to the circuit courts of appeals in 1891, there was no similar provision in the jurisdictiontal statute, and the circuit courts of appeals have never exercised this power. Wallace $v$. United States, 243 Fed. 300 (7th Cir.), cert. denied, 245 U.S. 650 (1917). For an excellent consideration of the problem, see Hall, Reduction of Criminal Sentences on Appcal: I, 37 CoLUMr. L. REv. 521 (1937). Although Courts of Appeals have spoken of a power to review where an abuse of discretion exists, they have nearly always found no such abuso to exist. E.g., United States v. Hetherington, 279 F.2d 792, 796 (7th Cir. 1960); Livers v. United States, 185 F.2d 807, 809 (6th Cir. 1950); Tincher v. United States, 11 F.2d 18, 21 (4th Cir. 1926); Goldberg v. United States, 277 Fed. 211, 220 (8th Cir. 1921).

12. 284 U.S. 299 (1932).

13. Id. at 305 . 
thorough analysis of this rule is found in Judge Frank's opinion in United States $v$. Rosenberg. ${ }^{14}$ Although he felt constrained to follow the precedent of Gurera and Blockburger, Judge Frank went on to express his own views. He found particular difficulty with 28 U.S.C. section 2105 (1958), which provides that an appellate court may "affirm, modify, vacate, set aside or reverse any judgment." Although this statute dates back to the first Judiciary Act of 1789, apparently no federal court had considered its impact on the issue of appellate review of a criminal sentence. Several state courts had construed similar statutes to allow such review. ${ }^{15}$ Judge Frank, however, felt obliged to leave to the Supreme Court the possibility of interpreting Section 2106 so as to permit review. ${ }^{16}$

The Court has not followed Judge Frank's suggested interpretation of Section 2106. Indeed it refused, in Gore $v$. United States, 17 to "enter the domain of penology, and more particularly that tantalizing aspect of it, the proper apportionment of punishment .... First the English and then the Scottish Courts of Criminal Appeal were given power to revise sentences, the power to increase as well as the power to reduce them .... This court has no such power."18 Thus, despite occasional dicta to the effect that a court may review a sentence to correct an abuse of discretion, it appears well settled that federal appellate courts will not review a sentence that is within statutory limits. ${ }^{10}$

Several cases, however, stand as exceptions to the rule of non-review. One group of cases develops the principle that review of a sentence for contempt

14. 195 F.2d 583, 604 (2d Cir.), cert. denied, 344 U.S. 838, rehcaring denied, 344 U.S. 889 (1952).

15. See PA. Stat. Ans. tit. 17, \& 41 (1962) and the construction given the statute by the Pennsylvania court in Commonwealth v. Garramone, $307 \mathrm{~Pa}$. 507, 161 Att. 733 (1932). See also 89 A.L.R. 295 (1934). For a recent case following Garramonc, see Commonwealth v. Green, $396 \mathrm{~Pa}$. 137, 151 A.2d 241 (1959). See Mfueller, Penology on Appeal: Appellate Review of Legal but Excessive Sentence, 15 VArd. L. Rev. 671, 677-82 (1962).

16. 195 F.2d at 605-07. The Supreme Court denied certiorari, 344 U.S. 835 (1952), and when it later denied a petition for rehearing, Mrr. Justice Frankfurter filed a separate memorandum opinion in which he stated:

One of the questions, however, first raised in the petition for rehearing is beyond the scope of the authority of this Court, and I deem it appropriate to say so. A sentence imposed by a United States district court, even though it be a death sentence, is not within the power of this Court to revise.

Rosenberg v. United States, 344 U.S. 889, 890 (1952).

17. 357 U.S. 386 (1958).

18. Id. at 393. Eleven states have some system of sentence review allowed by statute. Of these, nine vest the power in an existing appellate court while two, Mrassachusetts and Connecticut, have created special tribunals for this purpose. See Comment, 69 YALE L.J. 1453 (1960). See also note 15 sipra.

19. For cases implying that abuse of discretion may be reviewed, see note 11 supro. Among the recent cases upholding the rule of non-review, see United States v. Baysden, 326 F2d 629 (4th Cir. 1964) ; Boerngen v. United States, 326 F.2d 326 (5th Cir. 1964); Martin v. United States, 317 F.2d 753 (9th Cir. 1963). 
is permissible, since there is no statutory limit to such sentences..$^{20}$ The opinions in the remaining cases, ${ }^{21}$ Leach included, fail to articulate a single rationalizing basis for decision. Close examination of this group of decisions, however, reveals that they contain an implicit distinction between review of the merits of a sentence and review of the procedure leading to a sentence. ${ }^{22}$ Thus in the line of cases culminating in Leach, the courts have reviewed defects in sentencing procedure, despite the general rule of non-review.

In Townsend v. Burke ${ }^{23}$ the Supreme Court held that the constitutional protection of due process applies to sentencing. The defendant, unrepresented by counsel, had pleaded guilty and had been sentenced on the basis of erroneotts assumptions concerning his prior criminal record.24 The Court's opinion itmplicitly distinguished between review of the merits of a sentence and reviow of the procedure by which it was imposed:

It is not the duration or severity of this sentence that renders it constitutionally invalid; it is the careless or designed pronouncement of sentence

20. In Green v. United States, 356 U.S. 165 (1958), defendants were convicted of criminal contempt. On appeal the Supreme Court sustained the sentences but emphasized that:

[I]n the areas where Congress has not seen fit to impose limitations on the sentencing power for contempts the district courts have a special duty to exercise such an extraordinary power with the utmost sense of responsibility and circumspection. The "discretion" to punish vested in the District Courts . . . is not an unbridled discretion. Appellate courts have a special responsibility for determining that the power is not abused, to be exercised if necessary by revising themselves the sentences imposed.

Id. at 188. See United States v. United Mine Workers, 330 U.S. 258 (1947); and Yates v. United States, 356 U.S. 363 (1958). In the Yates case, having remanded once for re* sentencing, it later remanded with directions to reduce the sentence to the time petitioner had already served when the trial judge on initial remand had reimposed the origital sentence. The Court conceded that normally a reduction of sentence should be left to the sentencing court, but went on:

However, when in a situation like this the District Court appears not to have excrcised its discretion in the light of the reversal of the judgment but, in effect, to have sought merely to justify the original sentence, this Court has no alternative except to exercise its supervisory power over the administration of justice in the lower Id. at $366-67$.

courts by setting aside the sentence of the District Court.

21. Those cases where the prosecutor has consented and an appellate court has remanded to the trial court for resentencing are not relevant to the problem at hand. Sec Yarbrough v. United States, 151 F.2d 649 (5th Cir. 1945), per curiam, and Scott v. Unitcd States, 165 Fed. 172 (5th Cir. 1908).

22. It should be noted that the term procedure is used here in its broadest scnsc. The meaning of the term is not limited to those traditional aspects of right to counscl, right to notice and hearing, right to confrontation, etc. "Procedure" is meant to cover not only these traditional elements, but also the format and criteria which the judge uses in imposing sentences, including pre-sentencing reports, requests for probation and rcferrals for mental examination.

23. 334 U.S. 736 (1948).

24. See id. at 739-40. Compare Leach v. United States, 320 F.2d 670, 672 n.3 (D.C. Cir. 1963). 
on a foundation so extensively and naterially false, which the prisoner had no opportunity to correct by the services which counsel would provide, that renders the proceedings lacking in due process. ${ }^{25}$

The Townsend case might be read to hold that denial of due process results from: (1) absence of counsel at sentencing in some or all cases ; ${ }^{20}$ (2) villful use of erroneous pre-sentencing material; (3) some composite of these two elements. Two other Supreme Court cases, however, imply that even if counsel were present, other procedural defects in sentencing might constitute a violation of due process. ${ }^{27}$ A possible extension of Tozchsend applicable to Leach might be that not only a willful use of erroneous sentencing materials, but also a deliberate failure to use proper materials constitutes a violation of due process. But whether or not Leach can be justified on constitutional grounds, as a minimum these Supreme Court cases stand for the proposition that sentencing procedures may be reviewed to determine if a violation of procedural due process has occurred.

25. 334 U.S. at 741. The Toronsend case was cited by Mr. Justice Black in Williams v. New York, 337 U.S. 241, 252 n.18 (1949), for the proposition that "sentencing procedure is [not] immune from scrutiny under the due process clause" See also Smith v. United States, 223 F.2d 750 (5th Cir. 1955), rev'd on other grounds, 360 U.S. 1 (1959), for a case following the rationale of Townsend.

26. The Townsend case was decided long before Gideon v. Wainwright, 372 U.S. 335 (1963), which recognized the right to court appointed counsel in state courts. It is unclear in Tozensend whether the absence of counsel at sentencing or the use of erroncous matcrials in sentencing was the basis of the Court's decision. Query whether Gidcon requires that counsel be present at sentencing or is satisfied merely by his presence at trial,

-27. In one case, Gryger v. Burke, 334 U.S. 728 (1948), decided the same day as Tontnsend, the Court held 5-4 that the failure of the state to provide counsel for the defendant was not a denial of due process. However, the dissent referred specifically to a further error: namely, that the trial judge pronounced sentence under a misconception of the applicable law. Mr. Justice Rutledge was joined by Justices Black, Douglas, and AIurphy in dissent:

Gryger was sentenced to life imprisonment by a court working under the misconception that a life term was mandatory, not discretionary, under the Pennsylvania Habitual Criminal Act. ... It is immaterial that the same sentence might or probably would have been imposed in an exercise of the court's discretion. Petilioner was entitled to have sentence pronounced in that manner, not as an automatic mandate of statute. The denial of the very essence of the judicial process, which is the exercise of discretion where discretion is required, is in itself a denial of due process, not merefy an error of state law of no concern to this Court.

Id. at 733-34.

The majority had held on this point that (1) it was unclear that the trial judge had misconceived the statute, and (2) even if he had misconstrued the statute, this was a matter of Pennsylvania law. The majority feared that if this error were held a denial of due process, "every erroneous decision by a state court on state law would come here as a federal constitutional question." Id. at 731. It is possible to infer, however, that if the case had come from a federal court the Supreme Court majority would have been willing to examine the construction of the law as a matter of administering federal criminal justice (see note 36 infra), if not on due process grounds.

The other case implying broader review of sentencing procedure is Williams v. New York, 337 U.S. 241 (1949). See Mr. Justice Black's remark, id. at 252 n.18, quoted in note 25 sipra. 
Beyond the minimum constitutional requirements of due process, the several courts have found limitations on sentencing procedure implicit in various statutes. In United States $v$. Wiley ${ }^{28}$ the trial judge refused to consider the defendant for probation because he had insisted upon his constitutional right to a trial and had refused to plead guilty. The court of appeals held that the sentence was vitiated by the trial judge's refusal to consider the possibility of probation - authorized by statute - in the process of imposing sentence:

[T] he intention of Congress, under the Probation Act, requires that an application for probation by a defendant ... must be received and acted on by the court, regardless of whether the conviction is based on a plea of guilty or follows a trial .... Within the area defined by Congress, a district judge is required to act upon applications for probation made by persons convicted of crime. . . .20

Similarly, in Peters $v$. United States ${ }^{30}$ the D.C. Circuit vacated a maximum sentence imposed upon two adolescents convicted of robbery without pre-sentence investigation. The court read Federal Rule of Criminal Procedure 32,01 authorizing a pre-sentence investigation, to require such a procedure in this case. $^{32}$ Wiley and Peters thus support the argument of the D.C. Circuit in Leach that appellate review of the failure of a sentencing judge to follow a procedure required - explicitly or implicitly - by statute or Federal Rule is not barred by the rule of non-review.

In addition to constitutional and statutory limitations upon sentencing procedure, one court of appeals has exercised its inherent supervisory power over the administration of criminal law in federal district courts to review a sentence imposed by a district judge. On remand in the Wilcy case, the district court used the fact that the defendant had refused to plead guilty as a basis for imposing a more severe sentence on Wiley than on his confederates. The Seventh Circuit held that because the district court's sentencing criterion arbitrarily singled out one of a group of defendants for imposition of a severe sentence, the appellate court would "not hesitate to correct the disparity. In so doing it is exercising its supervisory control of the district court. . . ." While this case may represent an unusual use of the supervisory power, ${ }^{35}$ it cannot

28. 267 F.2d 453 (7th Cir. 1959).

29. Id. at 455 .

30. 307 F.2d 193 (D.C. Cir. 1962).

31. Rule 32(a) provides in pertinent part: "Before imposing sentence the court sliall afford the defendant an opportunity to make a statement in his own behalf and to present any information in mitigation of punishment." Rule 32 (c) provides in part: "the probation service of the court shall make a pre-sentence investigation and report to the court before the imposition of sentence... unless the court otherwise directs."

32. The court did not, however, give any indication of the scope of this interpretation.

33. 278 F.2d at 503. Wiley can be read as based on a constitutional right to trial. The concurrance emphasizes that "[a] defendant in a criminal case should not be punished by a heavy sentence merely because he exercises his constitutional right to be tried before an impartial judge or jury." Id. at 504 .

35. The court in Wiley cited Ia Buy v. Howes Leather Co., 352 U.S. 249, 259 (1957), for the existence of a supervisory power over the district court. This use of $L a$ Buy was 
be denied that federal appellate courts have inherent power to supervise the criminal procedures followed by trial courts. To date this power has been used largely to create and enforce judicially developed rules of evidence. ${ }^{30}$ But there seems no reason why appellate courts might not use this power to create and enforce sentencing procedures. ${ }^{37}$ Indeed, given the weakness of the statutory interpretation advanced in Leach, ${ }^{38}$ the case might be read as a judicial creation of a rule of procedure applicable to the sentencing process - in effect an application of the supervisory power.

Apart from the constitutional, statutory, and supervisory bases of power to review sentencing procedure, there are persuasive reasons in favor of such review. Initially it should be noted that the arguments which are most often advanced in opposition to appellate review on the merits of a criminal sentence are largely irrelevant to procedural review. For example, it is feared that once appellate courts begin to review sentences, every defendant will appeal. The postulated result is overcrowded dockets, frivolous appeals, and fatigued judges. Even if this were true with respect to review on the merits, ${ }^{30}$ the issues involved in determining a proper sentencing procedure, unlike the issues in-

criticized in a Note, 109 U. PA. L. REv. 422, 425 (1961), which cited Minnesota v. National Tea Co., 309 U.S. 551, 555 (1940), to support the assertion that the supervisory power is ancillary to the appellate power rather than independent of it. Cf. Note, What is the Proper Scope of Appellate Review of Sentencing?, 75 HARv. L. REv. 416, 417 (1961). This criticism appears inappropriate insofar as it relies on Mfinnesola $T c a$, which originated in a state court and did not involve the supervisory power of the federal judiciary over lower federal courts. See note 36 infra.

36. On the supervisory power of the Supreme Court over the administration of criminal justice in the lower federal courts, see the opinion by MIr. Justice Frankfurter in McNabb v. United States, 318 U.S. 332 (1943):

[T] he scope of our reviewing power over convictions brought here from the federal courts is not confined to the ascertainment of Constitutional validity. Judicial supervision of the administration of criminal justice in the federal courts implies the duty of establishing and maintaining civilized standards of procedure and evidence. Id. at 340 .

The Court of Appeals for the District of Columbia can formulate rules of cvidence for the lower courts of the District. Griffin v. United States, 336 U.S. 704 (1919). See also Durham v. United States, 214 F.2d 862, 874 n.44 (D.C. Cir. 1954); Linkins v. Prolestant Episcopal Cathedral Foundation, 187 F.2d 357, 361 (D.C. Cir. 1950). For the common law power of the other courts of appeals to promulgate rules of evidence, see Funk v. United States, 290 U.S. 371, 381-82 (1933), discussed in Note, 47 HARv. L. REv. 853 (1934).

37. See note 20 supra.

38. See Leach v. United States, 334 F.2d 945, 951-58 (D.C. Cir. 1964) (dissenting opinion), discussed in note 8 supra.

39. Canada has a statute (Stat. of Can. 1953-54, c. 51, $\S \S 556-57,583-84$ ) allowing appellate review of sentences, but has not been flooded with appeals. See statement by Justice G. Miller Hyde, Q.B. (Court of Appeal for the Province of Quebec), in Symposium - Appellate Review of Sentences, 32 F.R.D. 249, 306 (1963). Nor have the English been bothered with such a problem despite their statute (see text accompanying note 17 supra). Symposium, supra at 268, 269. And the Connecticut provisions for sentence review have not provoked such a flood of appeals. See Comment, 69 Y YrE L.J. 1453 (1960). 
volved in determining the proper severity of a sentence, can be framed with precision; consequently, it is to be expected that appellate courts can and will formulate definitive procedural rules for the sentencing process. ${ }^{40}$ Not only will trial courts receive adequate guidance under such rules, but also most procedural errors will be readily apparent and easily corrected on appeal. It thus seems unlikely that the availability of procedural review would generate a large number of time consuming appeals.

Probably the most substantial argument which can be mustered in favor of the doctrine of non-review rests upon the supposed close relationship between trial judges and defendants and upon the practical wisdom of trial judges accumulated through years of sentencing offenders. It is argued that this close relationship and experience affords an expert basis for decisions on sentencing that no appellate tribunal possesses. Special competence may be a good argutment against review on the merits, but it does not militate against the desirability of procedural review. When the reviewing court finds that the sentencing judge failed to follow a proper sentencing procedure, and therefore vacates the sentence and remands with directions to reconsider, its decision need not be based upon an intimate knowledge of the defendant. The appellate court does not consider the merits of the sentence, but only the procedure by which it was reached. The final decision is still made by the trial judge himself.

Procedural review, in fact, can be seen as a way of implementing the policy of the rule of non-review, by forcing trial judges to put their purported expertise to work. It is a technique through which an appellate court can force a trial judge to make use of his unique opportunities for gathering information in order to increase his knowledge of the defendant and to utilize his acquired experience more rationally. Particularly where there are statutory procedures available whereby the trial judge could have gained relevant knowledge of the offender, ${ }^{41}$ it seems entirely appropriate for an appellate court to vacate a sentence imposed in partial ignorance. The desirability of procedural revicw in sentencing in order to promote informed decisions regarding particular defendants is also supported by a basic philosophy of the federal sentencing statutes - that the sentence should be tailored to fit the particular defendant.49

A close analogy to these arguments in favor of review of sentencing procedure may be found in the relationship of courts to administrative agencies.

40. The narrow issues raised on appeal give precision to the rules established in Lcach and Wiley: a request for probation in Wiley; and for a mental examination in Leach. But compare Peters v. United States, 307 F.2d 193 (D.C. Cir. 1962), discussed in notes 30-32 and accompanying text, where the basis of the decision was less clear.

41. 18 U.S.C. $\$ 4208$ (1958) allows a federal trial judge to commit a convicted of fender for six months in order to study him mentally and emotionally. Final sentence is not pronounced until after the completion of the examination. See H.R. Rep. No. 1946, 85th Cong., 2d Sess. 9 (1958). Cf. H.R. Rep. No. 2579, 85th Cong., 2d Sess. (1958), Conference Report 2-3. It should be noted that $\S 4208$ applies in all federal courts, except those in the District of Columbia.

42. See, e.g., the materials cited in note 41 supra for manifestations of this philosophy, 
Courts have generally refused to review findings of fact by administrative agencies, because a major purpose for establishing such agencies is that they will bring to bear a special competence in dealing with complex factual problems. ${ }^{43}$ To this end courts often require agencies to utilize all available facts and relevant evidence in reaching their decisions. ${ }^{44}$ The same rensoning would seem to apply with equal force to the process of sentencing in the trial court; absent details concerning the particular defendant, any special competence possessed by the trial judge must operate in a vacuum. The argument from special knowledge and experience thus requires that the courts insist upon the maintenance of procedural standards that will force sentencing judges to bring their experience to bear only after the facts of the particular case are known. ${ }^{45}$

The analogy drawn from administrative law has implications far broader than merely establishing the principle that a trial judge must consider certain pre-sentence materials. As Dean Landis has pointed out: "The positive reason for declining review over administrative findings of fact is the belief that the expertness of the administrative, if guarded by adequate procedures, can be trusted to determine these issues as capably as judges." 40 The basic premise of Dean Landis' statement is that if the parties to a controversy are protected and guided by an adequate procedural system, ${ }^{\mathbf{4 7}}$ a proper and just decision will be obtained. ${ }^{48}$ If the sentencing process is marked by an absence of procedural rules and review, the parties will be less able to protect their own in-

43. Cf. NLRB v. Stow Manufacturing Co., 217 F.2d 900, 905 (1954). See also NLRB v. Standard Oil Co., 138 F.2d 885, 887 (2d Cir. 1943).

44. The Supreme Court has held in Morgan v. United States, 298 U.S. 468, 481 (1936) (Morgan I), that the administrator who decides must base his decision on the evidence.

45. When agencies have established their own standards for decision, a refusal to follow these rules in deciding a particular case will result in reversal by a revicwing court. This basis of decision was at issue in the Biseayne controversy, when the FCC spontaneously refused to follow its normal guide for granting television licenses. Sunbeam Television Corp. v. FCC, 243 F.2d 26, 28 (D.C. Cir. 1957). See also Beachview Broadcasting Corp. v. FCC, 273 F.2d 76, 77 (Bazelon, J., dissenting); SEC v. Chenery Corp., 318 U.S. 80 (1943), where the Court found that the SEC decision was not based on the named criteria and remanded with directions that the agency reach a decision consistent with its reasons.

46. Landis, The Adaministrative Process 142 (1938).

47. This is not to say that the same procedural safeguards that are available at trial must be applied to sentencing, but rather that certain minimum standards of fairness apply which are best expressed in clear rules.

48. See the remarks of Mrr. Justice Brandeis in St. Joseph Stock Yards Co. v. United States, 298 U.S. 38 (1936) (concurring opinion), which involved an administrative decision:

The supremacy of law demands that there shall be opportunity to have some court decide whether an erroneous rule of law was applied; and whether the proceeding in which facts were adjudicated was conducted regularly.

Id. at 84 . By analogy, one might infer that appellate courts must have similar power over sentencing procedure. 
terests and it will become more likely that the disposition of convicted offenders will be based on arbitrary or improper standards. ${ }^{40}$

The final reason supporting procedural review is the fact that the general doctrine of non-review itself is in disrepute. ${ }^{50}$ It has been attacked by judges who have enforced its letter, ${ }^{61}$ and several appellate judges have acknowledged the rule to be so uncongenial that when faced with excessive but legal sentences they tend to scrutinize the trial record closely in order to find an error upon which to base a reversal of the conviction. ${ }^{52}$ Moreover, the general movement toward articulation of sentencing standards and the reduction of sentencing disparities has found the rule of non-review a major impediment to the realization of its goals. ${ }^{63}$ Finally, the rule of non-review is condemned for its

49. Cf. the flippant attitude of the lower court in Townsend v. Burke, 334 U.S. 736, $739-40$ (1948), and the hopefully unique motivation of the sentencing judge criticized in United States v. Wiley, 278 F.2d 500 (7th Cir. 1960) (see text at note 29 stipra). Comparc the movement toward more complete standards in the administrative process as evidenced by the Administrative Procedure Act, 60 Stat. 237 (1946), as amended, 5 U.S.C. $\$ \$ 1001$ 11 (1958).

50. See, e.g., Mueller, Penology on Appeal: Appellate Revicw of Legal but Excessizic Sentences, 15 VANd. L. Rev. 671 (1962); Sobeloff, The Sentence of the Court: Should There be Appellate Review?, 41 A.B.A.J. 13 (1955); Hall, Reduction of Criminal Sentences on Appeal, 37 Coluns. L. Rev. (pts. I \& II) 521, 762 (1937); Sobeloff, A Rccommendation for Appellate Review of Criminal Sentences, 21 BrookuYN L. Rvv. 2 (1954).

51. See United States v. Rosenberg, 195 F.2d 583, 605 (2d Cir.), ccrt. dcrict, 344 U.S. 838 (1952). A questionnaire on appellate review was submitted to the judges attending the Judicial Conference of the Court of Appeals for the Second Circuit in September, 1962. On the question "should there be some review of sentences?" 38 judges (7 circuit, 31 dlstrict) voted yes, 6 (1 circuit, 5 district) voted no. Symposimm - Appellatc Revicze of Sentences, 32 F.R.D. 249, 319 (1962).

52. Judge Clark has said: "[I]n weighing whether the error is prejudicial, we have allowed an unusually harsh sentence to turn the balance." United States v. Hoffman, 137 F.2d 416, 422 (2d Cir. 1943). See Nash v. United States, 54 F.2d 1006 (2d Cir. 1932); Hall; -Reduction of Criminal Sentences on Appeal, II, 27 ColUr. L. REv. 762, 774-75 (1937).

53. Consider the remarks of Professor Mueller:

If law has drawn penology within its orbit, and in providing for penal and correctional sentences it has done so, it is obviously the duty of the appellate court to see to it that the law is properly served. This is an appellate function.

Mueller, supra note 50, at 685-86.

Nearly all commentators agree that sentence disparity presents a very real problem when dealing with disposition of convicted offenders. According to former Attorney Gen* eral Robert Kennedy, the solution to the problem lies not in maling sentences cqual but in making sentencing philosophies agree. Address by Robert F. Kennedy, Justice is Foumd in the Hearts and Minds of Free Men, Fed. Probation, Dec. 1961, p. 3.

In order to correlate sentencing philosophies and articulate sentencing standards, a general supervisory forum is required. As Chief Judge Sobeloff (4th Circuit) sees the problem:

If it is desirable to articulate generalized principles for measuring penalties, the appellate tribunal is precisely where the attempt should be made upon the foundation of the work of the district courts.

Symposium - Appellate Review of Sentences, 32 F.R.D. 249, 275 (1962). 
injustice and for its tendency to allow judicial errors to go uncorrected. In view of this widespread belief that the rule of non-review is undesirable, it would seem inappropriate to apply it mechanically to review of sentencing procedure.

The fact that procedural review of sentencing is thought desirable on policy grounds and justified by the line of precedent culminating in Leach still leaves the content of the procedural rules largely undefined. In the area of due process requirements, the issues of right to counsel and right to hearing are obvious starting places. ${ }^{55}$ Tentative definition has already begun in Wiley and Leach concerning procedural requirements based on statutory interpretation and the supervisory power. ${ }^{50}$ A logical extension of these cases would be to formulate more definite standards regarding the use of pre-sentence investigation facilities. The Peters case, for example, required use of pre-sentence reports but failed to designate the conditions in which such reports are necessary.5T Further articulation of such standards, however, would seem first to require a more careful consideration of and choice between the ultimate and often conflicting goals of the sentencing process. ${ }^{58} \mathrm{It}$ is such an important and potentially rewarding task that the Leach rule makes possible and necessary.

54. See id. at 266 .

55. See Townsend v. Burke, 334 U.S. 736 (1948); Gryger v. Burke, 334 U.S. 728 (1948); Williams v. New York, 337 U.S. 241 (1949). The absence of a clear rule on right to counsel at the sentencing is an obvious problem in both Tozusend and Gryger.

56. See note $\mathbf{4 0}$ supra.

57. Besides the problem of standards, there may arise a problem of judicial good faith. A trial judge who is directed to obtain a pre-sentence report on remand may do so but may also fail to give weight to its findings while purporting to consider them. Cf. People v. Henderson, 37 Cal. Rptr. 883 (Ct. App. 1964). But problems of judicial good faith seem unlikely to be of greater magnitude or frequency here than in many other areas of law.

58. For the conflict between deterrence, retribution, protection of society, and rehabilitation as criteria for setting sentences, see Comment, 69 YALE L.J. 1453 (1960); Comment, 72 Yale L.J. 368 (1962). See also the sources in DonNelly, Goldsters \& Schwastz, Crintral Lain 498-519 (1962). 